\title{
Evaluation of the roughness and mass loss of the flowable composites after simulated toothbrushing abrasion
}

\section{Avaliação da rugosidade e da perda de massa de resinas compostas "flow" após escovação simulada}

\author{
Fernanda Cristina Pimentel Garcia* \\ Linda Wang** \\ Paulo Henrique Perlatti D’Alpino* \\ João Batista de Souza*** \\ Paulo Amarante de Araújo**** \\ Rafael Francisco de Lia Mondelli****
}

\begin{abstract}
The purpose of this study was to measure mass loss and surface roughness changes of different brands of flowable resin composites after a simulated toothbrushing test. The null hypotheses were that there would be no differences in mass loss and no significant changes in surface roughness after this test and that there would be no correlation between the two variables. The tested materials were Aeliteflo (Bisco), Flow-It (Pentron), Flow-It LF (Pentron), Natural Flow (DFL) and Wave (SDI). Z100 (3M/ESPE) microhybrid and Silux Plus (3M/ESPE) microfilled resin composites were used as control materials. Twelve specimens ( $5 \mathrm{~mm}$ in diameter, $3 \mathrm{~mm}$ thick) of each material were prepared according to manufacturers' instructions. Toothbrushing abrasion was performed on all specimens from each of the materials using a simulator. The percentage mass loss and surface roughness were assessed before and after 100,000 brushstrokes, using a Sartorius analytical balance of $0.0001 \mathrm{~g}$ accuracy and a Hommel Tester T1000, respectively. The measurements of both properties were statistically compared by paired $t$-test and Tukey's test $(\mathrm{p}<0.05)$. All materials presented a statistically significant mass loss comparing initial and final values, with the exception of Flow-It LF. However, no difference was revealed when comparing the mass loss of the different tested materials. All materials became rougher and Wave presented statistically higher roughness compared to the other resin composites. Flowable resin composites did not seem to be superior to the control groups, and they can be expected to wear by mass loss and to have an increased roughness of surface after toothbrushing action. The anticipated null hypotheses were partially accepted.
\end{abstract}

DESCRIPTORS: Composite resins; Tooth abrasion; Surface properties; Toothbrushing.

RESUMO: O objetivo deste estudo foi mensurar a perda de massa e as alterações de rugosidade superficial de diferentes marcas de resinas compostas "flow" após teste de escovação simulada. A hipótese nula testada foi de que não haveria diferença de massa e rugosidade de superficie após o teste e de que não haveria correlação entre essas variáveis. Os materiais testados foram: Aeliteflo (Bisco), Flow-It (Pentron), Flow-It LF (Pentron), Natural Flow (DFL) e Wave (SDI). As resinas compostas Z100 (3M/ESPE) e Silux Plus (3M/ESPE) foram utilizadas como controle. Doze espécimes ( $5 \mathrm{~mm}$ de diâmetro, $3 \mathrm{~mm}$ de espessura) de cada material foram confeccionados de acordo com as instruções do fabricante. O teste foi conduzido em uma máquina de escovação simulada, em todos os espécimes de todos os materiais, totalizando 100.000 ciclos. Antes e depois do teste, a massa e a rugosidade de cada material foram aferidas por uma balança analítica Sartorius de 0,0001 g de precisão e pelo equipamento Hommel Tester T1000, respectivamente. Os valores obtidos foram comparados pelos testes $t$-pareado e Tukey (p $<0,05)$. Todos os materiais apresentaram diferenças estatísticas de perda de massa entre os valores iniciais e finais, com exceção da resina Flow-It LF. Entretanto, nenhuma diferença foi observada quando se comparou a porcentagem de perda de massa entre os diferentes materiais testados. Todos os materiais tornaram-se mais rugosos, sendo Wave, estatisticamente, o mais rugoso. As resinas compostas "flow" não demonstraram superioridade em relação aos materiais de controle, devendo-se esperar o desgaste por perda de massa do material e maior rugosidade após a ação da escovação. A hipótese nula antecipada foi parcialmente aceita.

DESCRITORES: Resinas compostas; Abrasão dentária; Propriedades de superficie; Escovação dentária.

\footnotetext{
${ }^{*} \mathrm{PhD}$ Students; ***PProfessors - Department of Operative Dentistry, Endodontics and Dental Materials, School of Dentistry of Bauru, University of São Paulo.

** Assistant Professor, Department of Operative Dentistry, School of Dentistry, University of North Paraná.

*** Assistant Professor, Department of Oral Rehabilitation, School of Dentistry of Goiânia, University of Goiânia.
} 
Garcia FCP, Wang L, D’Alpino PHP, Souza JB, Araújo PA, Mondelli RFL. Evaluation of the roughness and mass loss of the flowable composites after simulated toothbrushing abrasion. Braz Oral Res 2004;18(2):156-61.

\section{INTRODUCTION}

Flowable resin composite is a category of low viscosity resin composites. This formulation results in a material of low elastic modulus ${ }^{3,21}$. Due to this characteristic, it is recommended for clinical situations where oral forces need to be relieved, contributing to an even distribution of resultants ${ }^{3}$. Thus, it can be applicable as liners or to restore Class V preparations. Due to their relative fluidity, they are also recommended for use in locations that are difficult to access in occlusal restorations $^{3,21}$. They may also be used to restore cavity preparations after microabrasion, porcelain repair, enamel defects and to repair incisal areas of anterior teeth. Flowable materials are easily applied in some areas, but they are difficult to handle due to their viscosity ${ }^{3}$. The wide indication of flowable composites in the oral cavity will cause them to be subjected to adverse conditions. Wear is one of the greatest concerns regarding the durability of this material. Jones et al. ${ }^{11}(1972)$ defined wear as a progressive loss of substance from the surface of a body as a result of mechanical action. Depending on the degree of wear, a restoration can fail due to two main reasons: submargination ${ }^{19}$ or changes in surface roughness ${ }^{12}$.

Even though toothbrushing plays an important role in oral hygiene, its continuing action might cause some damage to the surface of teeth $^{1,4,6,7,8,9,16,19}$, and Class V resin composite restorations are a good example of this scenario. Wear or surface alterations caused by regular toothbrushing may affect the material roughness, making it more prone to plaque accumulation, and soft tissues inflammation ${ }^{14}$. Many studies discuss the factors involved in toothbrushing abrasion ${ }^{6,13, *}$. Material and dentifrice characteristics and their interaction produce different consequences on abraded teeth and restorations ${ }^{4,9}$. Resin composite characteristics such as particle size, shape and composition, organic matrix constitution and the curing system are important factors which interfere in its performance ${ }^{2,13,15,17}$. On the other hand, dentifrices should be as non-abrasive as possible while effective in promoting cleansing and debris removal ${ }^{9}$.

The aim of this study was to determine the mass loss and surface roughness of five flowable, one microhybrid and one microfilled resin compos- ites when subjected to a laboratory toothbrushing test. The null hypotheses were that there would be no differences in the mass loss and no significant changes in surface roughness after simulated toothbrushing tests and that there would be no correlation between the two variables. Furthermore, no differences among the performance of flowable resin composites on resistance to toothbrushing should occur.

\section{MATERIALS AND METHODS}

Five flowable resin composites were compared with one microhybrid and one microfilled resin composites. Tested materials are listed in Table 1.

Twelve specimens of each material were obtained from a silicone mold $(5 \mathrm{~mm}$ in diameter x $3 \mathrm{~mm}$ in thickness, Reforplás, São Paulo, SP, Brazil). After the insertion of the material into the mold, the surface was covered with a polyester matrix strip (TDV Dental Ltda., Santa Catarina, Brazil) that was slightly pressed using a glass slide. Polymerization was carried out with a visible light-curing unit (3M Curing Light XL 1500 - 3M/ ESPE Dental Products, St. Paul. MN, USA - model 5518AA, 100-240V , 50/60 Hz, Canada, X 101856) for $60 \mathrm{~s}$ at $500 \mathrm{~mW} / \mathrm{cm}^{2}$, which was periodically monitored with a light meter (Curing radiometer, Model 100P/N-150503/Demetron Research Corp., Danbury, CT, USA). After curing one side of the specimens, they were removed from the mold and the opposite side was irradiated in the same manner. Specimens were immediately polished with SofLex discs with cooling water (3M/ESPE Dental Products, St. Paul, MN, USA), from the coarse to fine granulation, during $15 \mathrm{~s}$ for each disk at low speed. Between each finishing step the specimens were cleaned in running water. Specimens were finally ultrasonically cleaned (Tempo Ultrasonic Ind. Com. Ltda. Taboão da Serra, SP, Brazil, mod. $\mathrm{T}-14,90 \mathrm{~W}$ ) in deionized water for 10 minutes to remove polishing debris. They were then identified and aged in deionized water at $37^{\circ} \mathrm{C}$. Specimens were weighed every $24 \mathrm{~h}$ for 2 weeks of aging time until they maintained a constant weight value for five consecutive days of measuring. The mass loss was assessed in an analytical balance (Sartorius, Werke A.G., Goettingten, Germany), accurate to $0.0001 \mathrm{~g}$.

\footnotetext{
*Wang L, Garcia FCP, Araújo PA, Franco EB, Mondelli RFL. Wear resistance of packable resin composites after simulated toothbrushing test. J Esthet Rest Dent 2004 (in press).
} 
Garcia FCP, Wang L, D’Alpino PHP, Souza JB, Araújo PA, Mondelli RFL. Evaluation of the roughness and mass loss of the flowable composites after simulated toothbrushing abrasion. Braz Oral Res 2004;18(2):156-61.

TABLE 1 - Materials used in the test*.

\begin{tabular}{|c|c|c|c|c|c|c|}
\hline Brand & Matrix & Filler & $\begin{array}{c}\text { Filler } \\
\text { content }(\mathrm{v} / \mathrm{v})\end{array}$ & $\begin{array}{c}\text { Filler } \\
\text { size }(\mu \mathrm{m})\end{array}$ & Manufacturer & $\begin{array}{l}\text { Batch } \\
\text { number }\end{array}$ \\
\hline Aeliteflo & BisGMA & $\begin{array}{l}\text { Barium glass, } \\
\text { silica }\end{array}$ & $43 \%$ & 0.7 to 0.8 & $\begin{array}{c}\text { Bisco, Inc. Dental } \\
\text { Products, Itasca, Illinois, } \\
\text { USA }\end{array}$ & 109036 \\
\hline Flow-It & BisGMA & $\begin{array}{l}\text { Barium boro- } \\
\text { fluorosilicate }\end{array}$ & $53 \%$ & 0.04 to 4 & $\begin{array}{c}\text { Pentron, } \\
\text { Wallingford, CT, USA }\end{array}$ & 810951 \\
\hline $\begin{array}{l}\text { Natural } \\
\text { Flow }\end{array}$ & $\begin{array}{c}\text { BisGMA, } \\
\text { dymethacrylic }\end{array}$ & $\begin{array}{l}\text { Boro silicate of } \\
\text { aluminum, silica }\end{array}$ & $43 \%$ & $\mathrm{NA}^{* *}$ & $\begin{array}{l}\text { DFL Ind. e Com., Rio de } \\
\text { Janeiro, RJ, Brazil }\end{array}$ & 97101051 \\
\hline Z100 & $\begin{array}{l}\text { BisGMA, } \\
\text { TEGDMA }\end{array}$ & Zirconia, silica & $71 \%$ & 0.6 & $\begin{array}{c}\text { 3M/ESPE Dental } \\
\text { Products, St. Paul, MN, } \\
\text { USA }\end{array}$ & 19970603 \\
\hline
\end{tabular}

*All information is supported by each manufacturer's profile. ${ }^{* *} \mathrm{NA}=$ not available.

The surface roughnesses were analyzed by a Hommel Tester T1000 (Hommelwerke, VS-Schwenningen, Germany, GmbH, Alte Tuttinger Strebe $20, \mathrm{D}-7730$ ) and expressed in $\mu \mathrm{m}$ as a roughness (Ra) value. This value means the average value that expresses the mean distance between the peaks and valleys of the surface profile. This device presents an accuracy of $0.01 \mu \mathrm{m}$. To record surface roughness measurements of the surfaces a device containing a diamond needle was used (Hommelwerke, VS-Schwenningen, Germany, t 1e, $-100590^{\circ} 1.6$ - 30/1.95 o.75/0; art nr.: 224160 gmbh). The radius of the needle was $5 \mu \mathrm{m}$ and the measurements were made at a constant speed of $0.15 \mathrm{~mm} / \mathrm{s}$ under a force of $0.8 \mathrm{mN}$. Surface roughness was randomly determined five times. The average of these readings was established as the baseline roughness value. The Ra range was previously established at $0.01 \mu \mathrm{m}$ to $0.8 \mu \mathrm{m}$ at a cut off of $0.25 \mathrm{~mm}$. Readings were obtained from a $1.5 \mathrm{~mm}$-long measurement.

Tests were conducted following ISO guidelines ${ }^{10}$. The abrasion test was performed in a mechanical toothbrushing machine ${ }^{20}$ similar to a Pepsodent machine equipped with six stainlesssteel holders. Six acrylic resin bases were used to keep two specimens in each base at the same time, extending $0.5 \mathrm{~mm}$ beyond its surface. Soft nylon-bristled toothbrush heads (Colgate Classic Colgate-Palmolive, Co., Osasco, SP, Brazil) with 25 planar tufts and 60 bristles per tuft were used under a $200 \mathrm{~g}$ load in a perpendicular direction to the sliding surface. A total of 100,000 strokes were performed at a frequency of approximately 374 strokes per minute. Stroke length was determined as $38 \mathrm{~mm}$. A slurry was prepared by mixing 2:1 of deionized water and Colgate MFP dentifrice (Colgate-Palmolive, Co., Osasco, SP, Brazil) immediately before testing, with a $\mathrm{pH}$ of 8.6. This slurry was constantly stirred to avoid the abrasive settling. The abrasion procedure was performed at a room temperature of $23^{\circ} \mathrm{C}( \pm 1)$. Toothbrushes were replaced for every new cycle of 50,000 strokes. Two specimens in each holder had their position switched after 50,000 strokes.

After the test, the specimens were cleaned in running water followed by an ultrasonic bath for 10 minutes. The surface roughness and mass loss were determined again in the abraded specimens and recorded as described before. For each material, variations of mass loss and surface roughness were determined by comparing the differences between initial and final measurements by paired $t$-test $(\mathrm{p}<0.05)$. Average mass loss percentage 
Garcia FCP, Wang L, D’Alpino PHP, Souza JB, Araújo PA, Mondelli RFL. Evaluation of the roughness and mass loss of the flowable composites after simulated toothbrushing abrasion. Braz Oral Res 2004;18(2):156-61.

TABLE 2 - Means in grams and standard deviation (SD) of initial (IM), final (FM) difference of mass loss (D) and percentage loss (\%) after simulated toothbrushing.

\begin{tabular}{l|c|c|c|c}
\hline \hline \multicolumn{1}{c|}{ Material } & IM (SD) & FM (SD) & D (SD) & $\%$ \\
\hline Natural Flow & $0.0895(0.0040) \mathrm{A}$ & $0.0877(0.0041) \mathrm{B}$ & $0.0018(0.0008) \mathrm{a}$ & 2.04 \\
\hline Aeliteflo & $0.0860(0.0032) \mathrm{A}$ & $0.0827(0.0035) \mathrm{B}$ & $0.0032(0.0011) \mathrm{a}$ & 3.77 \\
\hline Flow-It LF & $0.1169(0.0062) \mathrm{A}$ & $0.1142(0.0058) \mathrm{A}$ & $0.0027(0.0068) \mathrm{a}$ & 2.12 \\
\hline Silux Plus & $0.0949(0.0056) \mathrm{A}$ & $0.0921(0.0061) \mathrm{B}$ & $0.0029(0.0024) \mathrm{a}$ & 3.04 \\
\hline Flow-It & $0.0985(0.0059) \mathrm{A}$ & $0.0958(0.0065) \mathrm{B}$ & $0.0026(0.0027) \mathrm{a}$ & 2.70 \\
\hline Z100 & $0.1228(0.0101) \mathrm{A}$ & $0.1211(0.0102) \mathrm{B}$ & $0.0017(0.0005) \mathrm{a}$ & 1.29 \\
\hline Wave & $0.0868(0.0101) \mathrm{A}$ & $0.0849(0.0097) \mathrm{B}$ & $0.0019(0.0011) \mathrm{a}$ & 2.19 \\
\hline \hline
\end{tabular}

Same lowercase letters indicate no differences among the values of the lines in the same column (Tukey's test; $p<0.05)$. Same uppercase letters indicate no differences between the values of the columns of the same line (paired $t$-test; $\mathrm{p}<0.05$ ).

and final roughness were also calculated and results were analyzed by one-way ANOVA followed by Tukey's multiple comparisons test at $\alpha=0.05$. Correlation between mass loss and surface roughness was calculated $(\mathrm{p}<0.05)$.

\section{RESULTS}

All materials showed mass loss after the simulated toothbrushing test ( $\mathrm{p}<0.05$ ), but Flow-It LF did not show a statistically significant difference $(\mathrm{p}=0.20)($ Table 2$)$

No significant differences in mass loss were observed among all tested resin composites $(\mathrm{p}=0.43)$. Even though there were no statistical differences, Aeliteflo (3.77\%) demonstrated higher wear, followed by Silux Plus (3.04\%). On the other hand, Z100 presented smaller mass loss (1.29\%).

Surface roughness measurements are shown in Table 3.

Regarding roughness, all materials became rougher after the test. Aeliteflo and Natural Flow flowable composites did not present statistical differences between initial and final roughness $(p>0.05)$. Comparing the final roughness among the tested materials, only Wave flowable composite was statistically rougher than all other resin composites $(\mathrm{p}<0.05)$. Z100 presented the second roughest surface, but it was not statistically different from Flow-It and Silux Plus. However, there was no difference when comparing these two materials to other tested materials, with the exception of Wave flowable composite $(\mathrm{p}<0.05)$. No correlation was detected between mass loss and surface roughness. Pearson correlation was calculated with $\mathrm{r}=-0.0296$.
TABLE 3 - Means and standard deviation (SD) of initial (IR) and final (FR) roughness $(\mu \mathrm{m})$ after simulated toothbrushing.

\begin{tabular}{l|c|c}
\hline \hline \multicolumn{1}{c|}{ Material } & IR (SD) & FR (SD) \\
\hline Natural Flow & $0.4815(0.0648) \mathrm{A}$ & $0.5435(0.1478) \mathrm{Aa}$ \\
\hline Aeliteflo & $0.4931(0.0828) \mathrm{A}$ & $0.5437(0.1950) \mathrm{Aa}$ \\
\hline Flow-It LF & $0.4293(0.1238) \mathrm{A}$ & $0.5890(0.1587) \mathrm{Ba}$ \\
\hline Silux Plus & $0.3430(0.0675) \mathrm{A}$ & $0.6179(0.2129) \mathrm{Bab}$ \\
\hline Flow-It & $0.4707(0.0771) \mathrm{A}$ & $0.6307(0.2095) \mathrm{Bab}$ \\
\hline Z100 & $0.6588(0.1721) \mathrm{A}$ & $0.9083(0.2066) \mathrm{Bb}$ \\
\hline Wave & $0.4742(0.0988) \mathrm{A}$ & $1.7612(0.4127) \mathrm{Bc}$ \\
\hline \hline
\end{tabular}

Same lowercase letters indicate no differences among the values of the lines in the same column (Tukey's test; $\mathrm{p}<0.05)$. Same uppercase letters indicate no differences between the values of the columns of the same line (paired $t$-test; $\mathrm{p}<0.05$ ).

\section{DISCUSSION}

The processes involved in the mechanisms of wear of the composites are very complex and not well understood. Wear is defined as loss of material substance resulting in loss of anatomic form ${ }^{19}$. Ferracane $^{5}$ (1994) also pointed out the possibility of component elution from the composite and its biological implications in the mechanism of wear. Besides the wear produced by abrasion, there are other types of wear generated by corrosion and fatigue $^{1}$. A clinical evaluation of these materials is a difficult task, since some factors such as dietary habits and chewing forces might influence the results ${ }^{1,9,16}$.

In the present study, the wear of flowable resin composites was tested by toothbrushing simulation. The abrasion mechanism of the composite 
Garcia FCP, Wang L, D’Alpino PHP, Souza JB, Araújo PA, Mondelli RFL. Evaluation of the roughness and mass loss of the flowable composites after simulated toothbrushing abrasion. Braz Oral Res 2004;18(2):156-61.

resins can be explained as wear of the resin (organic portion), leading to the creation of spaces that vary according to the size of the filler, thus increasing its roughness ${ }^{15}$. Previously, emphasis on filler properties was the most relevant parameter to obtain more resistant resin composites. However, the organic matrix composition and silane bonding agent are also important factors involved in the improvement of the mechanical properties of resin composites $^{2,13}$. Additionally, curing systems applied to polymerize these resin composites can also lead to different performance ${ }^{17,18}$. All these features need to be considered when different products are compared in any mechanical test.

Even though there is a tendency to correlate surface wear with roughness ${ }^{12, *}$, statistical analyses did not demonstrate a correlation between these two properties. The smallest mass loss was observed in Z100 material, even though no significant differences were found among groups. The results of this study are in agreement with another study where $Z 100$ presented the best results in simulated toothbrushing as well as in clinical evaluation $^{7} . Z 100$ contains the greatest ratio of filler with $71 \%$ in volume and $84.5 \%$ in weight. Additionally, the mean size of particles $(0.6 \mu \mathrm{m})$ and their distribution might help to reduce the amount of exposed organic matrix more prone to abrade. Wear resistance depends on the so-called interparticular space. The smaller and more homogeneous the fillers, the closer they will be, thus reducing the amount of exposed organic matrix and also the amount of wear ${ }^{3}$. Aeliteflo presented the largest mass loss among all tested materials in this study. Flowable resin composites generally present mean filler particle distribution ranging from 0.04 to $4 \mu \mathrm{m}$, thus demonstrating that, in this type of test, the higher the percentage of the inorganic component, the higher the wear resistance. Although no statistical difference was detected between Silux Plus and flowable resin composites, Silux Plus showed the second greatest mass loss, probably due to the smaller concentration of inorganic particles in volume and weight (40 and $52 \%$, respectively), with a higher percentage of resin matrix. Its pre-cured particles of colloidal silica are uniformly distributed within the organic matrix, being homogeneously worn. Frequently, the wear of this type of microfilled resin is due to the rupture of the links between these pre-cured particles and the organic matrix ${ }^{15}$.

After testing, Wave flowable composite presented the roughest surface. This material contains
$65 \%$ of strontium glass and silica filler particles by weight. Based on the results of this study, it can be concluded that the higher release and exposure of the filler, the inferior the behavior of the material (Table 3). Z100, Flow-It, Flow-It LF and Silux Plus became rougher after this test (Table 3). One can speculate that it could be because of the exposure of some filler particles resulting in the occurrence of matrix wear after toothbrushing. Aeliteflo and Natural Flow had similar surfaces when initial and final tests were compared (Table 3). One reason might be due to their filler composition, shape and size. As previously stated, monomer composition is receiving increased attention in the resin composite formulation to obtain improved mechanical resistance rather than an increase in the hardness of the filler particles ${ }^{13,18}$. Most of the conventional resin composites are composed of BisGMA. Its high viscosity requires diluents such as TEGDMA. UDMA, a dimethacrylate, is also often present in recent compositions. Different compositions are proposed by manufactures in an attempt to overcome the shortcomings; however, further investigations are necessary to evaluate whether these changes promote superior mechanical properties or not ${ }^{18}$. Distinct formulations under the same test conditions can determine differences on the polishing action of dentifrice as well as the interaction between the surface of composite and abrasive particles, as described by Grabenstetter et al. ${ }^{8}$ (1958). The surface roughness of resin composites is an inherent factor of the material, due to the heterogeneous nature of its components, such as size, type and shape of the fillers, quality and amount of organic component, type of union and system of curing ${ }^{15}$. In the present study, each resin composite presented a distinct performance, suggesting that the results were dependent on inherent formulation. The major problem related to mass loss is the resultant surface roughness that might have as a consequence restoration staining, plaque and food accumulation and gingival irritation $^{14}$. Thus, it can be expected that restorative materials have satisfactory roughness surface and high enough wear resistance to be satisfactory in clinical service for a long period of time ${ }^{14}$. Information regarding all the properties is mandatory prior to routine use of flowable composite resins.

\section{CONCLUSIONS}

Based on the results of this study, the anticipated null hypotheses were partially accepted. 
Garcia FCP, Wang L, D’Alpino PHP, Souza JB, Araújo PA, Mondelli RFL. Evaluation of the roughness and mass loss of the flowable composites after simulated toothbrushing abrasion. Braz Oral Res 2004;18(2):156-61.

It can be concluded that not all resins presented significant mass loss after simulated toothbrushing. Similar performance was observed among the tested materials. Even though different results were obtained by comparing different resin composites, all tested materials presented an increase in the surface roughness after simulated tooth-

\section{REFERENCES}

1. Aker JR. New composite resins: comparison of their resistance to toothbrush abrasion and characteristics of abraded surfaces. J Am Dent Assoc 1982;105:633-5.

2. Asmussen E, Peutzfeldt A. Influence of UEDMA, BisGMA and TEGDMA on selected mechanical properties of experimental resin composites. Dent Mater 1998;14:51-6.

3. Bayne SC, Thompson JY, Swift EJ Jr, Stamatiades P, Wilkerson M. A characterization of first-generation flowable composites. J Am Dent Assoc 1998;129:567-77.

4. Ehrnford L. Surface microstructure of composite resins after toothbrush-dentifrice abrasion. Acta Odontol Scand 1983;41:241-5.

5 . Ferracane JL. Elution of leachable components from composites. J Oral Rehabil 1994;21:441-52.

6. Gil FJ, Espias A, Sánchez LA, Planell JA. Comparison of the abrasive wear resistance between amalgams, hybrid composite material and different dental cements. Int Dent J 1999;49:337-42.

7. Goldstein GR, Lerner T. The effect of toothbrushing on a hybrid composite resin. J Prosthet Dent 1991;66:498500.

8. Grabenstetter RJ, Broge RW, Jackson FL, Radjke AW. The measurement of the abrasion of human teeth by dentifrice abrasives: a test utilizing radioactive teeth. J Dent Res 1958,37:1060-8.

9. Heath JR, Wilson HJ. The effect of dentifrices on restorative materials. J Oral Rehabil 1974;1:47-54.

10. International Organization for Standardization. Technical specification 14569-1. Dental materials - guidance on testing of wear resistance - Part 1: wear by tooth brushing. Switzerland, ISO; 1999.

11. Jones DW, Jones PA, Wilson HJ. A simple abrasion test for composites. J Dent 1972;1:28-34.

12. Kanter J, Koski RE, Martin D. The relationship of weight loss to surface roughness of composite resins from brushing. There was no correlation between wear and roughness.

\section{ACKNOWLEDGEMENT}

This work was supported by The State of São Paulo Research Foundation (FAPESP) 98/13822-7.

simulated toothbrushing. J Prosthet Dent 1982;47:50513.

13. Kawai K, Iwami Y, Ebisu S. Effect of resin monomer composition on toothbrush wear resistance. J Oral Rehabil 1998;25:264-8.

14. Lindquist B, Emilson CG. Distribution and prevalence of mutans streptococci in the human dentition. J Dent Res 1990;69:1160-6.

15. O’Brien WJ, Yee J Jr. Microstructure of posterior restorations of composite resin after clinical wear. Oper Dent 1980;5:90-4.

16. Rios D, Honório HM, de Araujo PA, Machado MA. Wear and superficial roughness of glass ionomer cements used as sealants, after simulated toothbrushing. Pesqui Odontol Bras 2002;16:343-8.

17. St-Georges AJ, Swift EJ, Thompsom JY, Heymann HO. Irradiance effects on the mechanical properties of universal hybrid and flowable hybrid resin composites. Dent Mater 2003; 19:406-13.

18. Tanoue N, Matsumura H, Atsuta M. Analysis of composite type and different sources of polymerization light on in vitro toothbrush/dentifrice abrasion resistance. J Dent 2000;28:355-9.

19. Turssi CP, de Magalhães CS, Serra MC, Rodrigues Jr AL. Surface roughness assessment of resin-based materials during brushing preceded by $\mathrm{pH}$-cycling simulations. Oper Dent 2001;26:576-84.

20. Vieira DF. Studies of hardness and abrasion resistance of acrylic resins [Master's thesis]. Indianapolis: Indiana University of Dentistry; 1960.

21. Yazici AR, Ozgunaltay G, Dayangac B. The effect of different types of flowable restorative resins on microleakeage of class V cavities. Oper Dent 2003;28:773-8.

Received for publication on Jul 14, 2003

Sent for alterations on Sep 10, 2003

Accepted for publication on Apr 05, 2004 